\author{
V. Karlov ${ }^{1}$, O. Kuznietsov ${ }^{1}$, A. Artemenko ${ }^{2}$, A. Karlov ${ }^{1}$ \\ ${ }^{1}$ Ivan Kozhedub Kharkiv National Air Force University, Kharkiv, Ukraine \\ ${ }^{2}$ General Staff of the Armed Forces of Ukraine, Kyiv, Ukraine
}

\title{
EVALUATION OF THE ACCURACY OF MEASURING THE RADIAL VELOCITY OF A TARGET WITH AN EXPONENTIAL AND ALTERNATING DECREASE IN PHASE CORRELATION OF THE BURST RADIO SIGNAL
}

\begin{abstract}
The article deals with the estimation of the radial velocity when using a coherent burst of radio pulses as applied to the presence of correlated fluctuations of the initial phases in the radio pulses reflected from the target. The accuracy of the measurement of the burst frequency is evaluated for case of coordinated processing without taking into account the phase fluctuations. The signals at the input of the radar's receiver is an additive mixture of signals reflected from the targets, and uncorrelated Gaussian noise, that is the assumption of investigating. It is assumed, that the phase fluctuations of the received radio pulses bursts are distributed according to normal probability laws with zero mean, and correlations of phase fluctuations decrease with exponential or alternating, sign-variable laws by increasing interval between radio pulses within the bursts. This analysis makes it possible to determine the conditions under which the complication of the processing algorithm for this radar signal is considered justified.
\end{abstract}

Keywords : coherent pulse radar; burst of radio pulses; phase fluctuations; radial velocity; Gaussian noise; radar surveillance; optimization efficiency.

\section{Introduction}

Problem statement. The improvement and development of modern aerodynamic objects of radar observation causes an increase in the requirements for their means of detection and tracking.

The increase in maneuvering capabilities of targets and the ability of them perform assigned tasks at low altitudes with rounding of the terrain makes it necessary to estimate the derived distance to a target with different radars with the highest possible accuracy.

Determination of the radial velocity of the target during the primary processing of radar information is implemented in coherent-pulse radar, which use a coherent burst of radio pulses as a sounding signal. The degree of coherence of this burst determines the duration of its phase structure and as a consequence, the measure of radial velocity resolution and the accuracy of measurement of the radial velocity of an air object.

Real condition of propagation and reflection of a radar signal can significantly limit of its temporal coherence and the quality of its time-frequency processing. These conditions include the influence of atmospheric heterogeneities [1], the Doppler noise of a target [2], and the reflection of radio waves from the earth's surface with complex terrain relief [3].

Evaluation of a possible reduction in the accuracy of measuring the radial velocity of the target due to the phase fluctuations of the signal allows determining the conditions for expediency of its optimization.

Analysis of recent research and publications. A large amount of work is devoted to radar observation of targets and the measurement of their coordinates and motion parameters in difficult conditions.

The distortions of the phase structure of the radar signal have different origin.

Fluctuations of phase due to the presence of atmospheric in homogeneities and features of the use of radio systems in the conditions of their influence are described in the works $[1,4]$.
In addition, the target's complex form and the its ability to the implementation of a sudden maneuver, causes walk it radar center and, consequence, the appearance of phase distortion received signal and target's high-speed noise $[1,4]$. If radar observation is implemented on the target of moving the small angles place, it is due to a lot of beams the spread of radar signal appear it additional phase distortion, which are considered in the $[4,5]$.

In modern coherent-pulse radars with digital processing, a coherent burst of radio pulses is used to provide radar observation of complex maneuvering targets. Therefore, it is of practical value to estimate the errors in measurement the radar velocity of a target depending on the statistical characteristics of the phase fluctuations of the radio pulses of a received burst.

The method of calculating the measurement error of a burst frequency resulting from the influence of phase fluctuations of its radio pulses is given in [6]. As shown in [7], the possible values of the measurement error of the radial velocity of the target, which appear due to phase distortion of the radio pulse burst, can exceed the allowable values for radars of different wavelength ranges.

The purpose of the article is to analysis the influence of the statistical characteristics of the fluctuations of the initial phases of radial pulses of a received coherent burst on the decrease in the accuracy of measuring the radial velocity of a target.

\section{Main material}

Evaluation of the radial velocity of the target is carried out according to the formula (1)

$$
V_{r}=(\lambda /(4 \pi)) \cdot \Omega
$$

where $\Omega=2 \pi F_{\partial}-$ cyclic Doppler frequency shift; $F_{\partial}-$ Doppler frequency; $\lambda$ - wavelength radar signal. Below we obtain the dispersion formula for the total measurement error $\sigma_{\Sigma}^{2}$ for the rectangular burst of radio pulses. 
It is assumed that the received signal is the sum of the burst of radio pulses reflected from the target and the internal noise of the receiving device

$$
y(t, \Omega)=x(t, \Omega)+n(t),
$$

where $y(t, \Omega)$ - the realization of the a received fluctuation; $x(t, \Omega)$ - the realization of the useful signal; $n(t)$ - the realization of internal Gaussian noise.

A useful signal is a coherent burst of radio pulses with a random amplitude and initial phase, the complex amplitude of which is described by the expression

$$
\dot{X}(t, \Omega)=b \sum_{i=1}^{n} \dot{X}_{i}(t, \Omega) \exp [j(\beta)],
$$

where $\dot{X}_{i}(t, \Omega)$ - complex amplitude i-th radio pulse; $b$ - random amplitude of the signal, distributed according to the Rayleigh law; $\beta$ - random initial phase, distributed according to a uniform law; $i$ - number of radio pulse, counted from the beginning of the burst; $n$ number of radio pulses in the burst.

In [1] it is noted that the likelihood ratio for a coherent signal with uniformly distributed random initial phase and random amplitude, distributed according to the Rayleigh law, as a result of statistical averaging over random parameters $b$ and $\beta$ has the form

$$
\ell(\Omega)=\frac{1}{1+q^{2} / 2} \exp \frac{q^{2} / 2}{2\left(1+q^{2} / 2\right)}\left|Z_{H}(\Omega)\right|^{2},
$$

where $q^{2}$ - signal-to-noise ratio in power; $\left|Z_{H}(\Omega)\right|^{2}$ - the square of the module of the complex weight integral as a function of the measured parameter.

Under regular measurement conditions $\left(q^{2}>>1\right)$, fairness is equality

$$
\left|Z_{H}(\Omega)\right|=\left|Z_{H}\left(\vec{\Phi}_{c}, \vec{\Phi}_{o}\right)\right| \approx q \rho\left(\vec{\Phi}_{c} \vec{\Phi}_{o}\right)=q \rho(\Omega),
$$

where $\quad \vec{\Phi}_{c}=\left\|\Phi_{c i}\right\|^{T} \quad(i=1,2, \ldots, n)$ - vector of observed values of the initial phases of the radio pulses; $\vec{\Phi}_{o}=\left\|\Phi_{o i}\right\|^{T}$ - vector of expected values of the initial phases of the radio pulses; $\rho\left(\vec{\Phi}_{c}, \vec{\Phi}_{o}\right)=\rho(\Omega)$ normalized mismatch function for the initial phase of the observed and expected radio signals.

The likelihood ratio takes the form $\left(q^{2}>>1\right)$

$$
\ell(\Omega) \approx \frac{2}{q^{2}} \exp \frac{q^{2} \rho^{2}(\Omega)}{2} .
$$

As shown in [6], in the case of coherent radio pulse burst with a constant period of repetition, the square of the normalized mismatch frequency function is described by the expression

$$
\rho^{2}(\Omega)=1-\frac{1}{2} \sum_{i=1}^{n} \sum_{j=1}^{n} \xi_{i} \xi_{j}\left(\Phi_{i}-\Phi_{j}\right)^{2}-
$$

$$
\begin{gathered}
-\frac{1}{2} T^{2} \Omega^{2} \sum_{i=1}^{n} \sum_{j=1}^{n} \xi_{i} \xi_{j}(i-j)^{2}+ \\
+T \Omega \sum_{i=1}^{n} \sum_{j=1}^{n} \xi_{i} \xi_{j}(i-j)\left(\Phi_{i}-\Phi_{j}\right),
\end{gathered}
$$

where $\Omega=\omega-\omega_{0}-$ mismatch between the expected $\omega$ and the observed $\omega_{0}$ cyclic frequencies of the burst radio pulses; $i, j$ - numbers of pulses, counted from the beginning of the burst; $\Phi_{i}, \Phi_{j}$ - observed values of the initial phase of the $i$-th and $\mathrm{j}$-th radio pulses, respectively; $\quad \xi_{i}=\frac{Z_{i}}{Z_{\Sigma}} \quad ; \quad Z_{i}=\frac{1}{2}\left|\int_{-\infty}^{\infty} \dot{Y}_{i}(t) \dot{X}_{i}^{*}(t) d t\right|$ module of the signal part of the complex correlation integral of the $\mathrm{i}$-th radio pulse; $\dot{\mathrm{Y}}_{i}(t)$ - complex envelope of the received $\mathrm{i}$-th radio pulse; $\dot{\mathrm{X}}_{i}^{*}(t)$ complex conjugate reference envelope when processing the $\mathrm{i}$-th radio pulse; $\mathrm{Z}_{\Sigma}=\sum_{i=1}^{n} \mathrm{Z}_{i} ; \quad T$ - period following the radio pulse of the burst.

According to [1], it is determined that the estimation of the Doppler shift of the frequency of the radio pulse burst can be carried out by finding the argument of the maximum natural logarithm of the likelihood ratio (6)

$$
\widehat{\Omega}=\arg \max \ln \ell(\Omega) .
$$

For a symmetric amplitude distribution of radio pulses in burst $\xi_{i}=\xi_{n+1-i}$, substituting expression (7) into expression (6), logarithmizing and leaving only the terms dependent on the measured parameters, we obtain an expression for sufficient statistics

$$
\begin{gathered}
S(\Omega)=-\frac{q^{2}}{2}\left\{\frac{T^{2}}{2} \Omega^{2} \sum_{i=1}^{n} \sum_{j=1}^{n} \xi_{i} \xi_{j}(i-j)^{2}-\right. \\
\left.-T \Omega \sum_{i=1}^{n} \sum_{j=1}^{n} \xi_{i} \xi_{k}(i-j)\left(\Phi_{i}-\Phi_{j}\right)\right\} .
\end{gathered}
$$

The estimation and dispersion of the error estimate of the frequency of the burst of radio pulses are obtained according to the method of maximum likelihood ratio [1] according to the expressions:

$$
\frac{d S(\Omega)}{d \Omega}=0 \text { provided } \Omega=\widehat{\Omega},
$$

$$
\frac{1}{\sigma_{\Omega}^{2}}=-\frac{d^{2} \ln \ell(\Omega)}{d \Omega^{2}}=-\frac{d^{2} S(\Omega)}{d \Omega^{2}} \text { provided } \Omega=\widehat{\Omega},
$$

where $\ln \ell(\Omega)$ - natural logarithm of the likelihood ratio (6) or its sufficient statistic $S(\Omega) ; \widehat{\Omega}$ - evaluation of the frequency of the radio pulse burst. 
After a single and double differentiation of the measured parameter of sufficient statistics (9), we obtain the estimate and dispersion of the frequency estimation error in the following form

$$
\begin{gathered}
\widehat{\Omega}=\sum_{j=1}^{m} \xi_{j}(2 j-1) R_{j} / T \sum_{j=1}^{m} \xi_{j}(2 j-1)^{2}, \\
\frac{1}{\sigma_{\Omega}^{2}}=\frac{q^{2} T^{2}}{2} \sum_{j=1}^{m} \xi_{j}(2 j-1)^{2}
\end{gathered}
$$

where $R_{j}$-difference of the initial phases of the $j$-th symmetric pair of radio pulses; $m$ - number of pairs of radio pulses symmetrical about the center of the burst.

If the burst of radio pulses has a rectangular envelope $\left(\xi_{i}=1 / n\right)$, expressions (12) and (13) can be converted to a form

$$
\begin{gathered}
\widehat{\Omega}=\frac{3}{m\left(4 m^{2}-1\right) T} \sum_{j=1}^{m}(2 j-1) R_{j}, \\
\frac{1}{\sigma_{\Omega}^{2}}=\frac{q^{2}\left(4 m^{2}-1\right)}{12} T^{2} .
\end{gathered}
$$

Random frequency measurement error due to fluctuations of the initial phases of the burst pulses can be represented by an expression

$$
\Delta \Omega=\frac{3}{m\left(4 m^{2}-1\right) T} \sum_{j=1}^{m}(2 j-1) \Delta R_{j},
$$

where $\Delta R_{j}$ - fluctuations of the initial phases difference of the $j$-th symmetric pair of radio pulses.

The dispersion of this error is determined by the expression

$$
\sigma_{\Omega \phi л}^{2}=\frac{9}{m^{2}\left(4 m^{2}-1\right)^{2} T^{2}}\left\langle\left[\sum_{j=1}^{m}(2 j-1) \Delta R_{j}\right]^{2}\right\rangle,
$$

where \langle\rangle - operation of statistical averaging.

The dispersion of the overall measurement error of the frequency of the burst of radio pulses is determined by the sum of the error dispersion $\sigma_{\Omega}^{2}$ due to the influence of the receiver's internal noise (15) and the error dispersion $\sigma_{\Omega \phi л}^{2}$ caused by the phase fluctuations of the burst's radio pulses (17)

$$
\sigma_{\Sigma}^{2}=\sigma_{\Omega}^{2}+\sigma_{\Omega \phi \pi}^{2}
$$

It is believed that the phase fluctuations of the radio pulses of the received burst are distributed according to the normal low with zero mean, and the correlation of the phase fluctuations of the neighboring radio pulses of the burst decreases exponentially and alternatingly [1].

In this case, the correlation matrix of phase fluctuations has the form [8-11]:

$$
K_{\varphi}=\left\|\sigma_{\varphi}^{2} a^{|i-j|}\right\| i, j \in 1,2, \ldots, n,
$$

where $\sigma_{\varphi}^{2}$ - dispersion of phase fluctuations; $a$ correlation coefficient of the phase fluctuations of neighboring radio pulses of the burst; $i$ and $j$ numbers of radio pulses of the burst.

In Fig. 1 shows that with positive values a, with an increase in the interval between the radio pulses of a burst, correlation decreases according to the exponential law, and with negative values a - according to an alternating sign.

The results of the experiment to determine the statistical characteristics of radar signals reflected from local objects outside the line of sign when radio waves propagate over the sea are shown in [12].

The obtained histograms of the distribution of the initial phase of the reflected signal of the 35D6D radar are fitted with a curve corresponding to the normal distribution, and the normalized correlation function has an oscillating character.

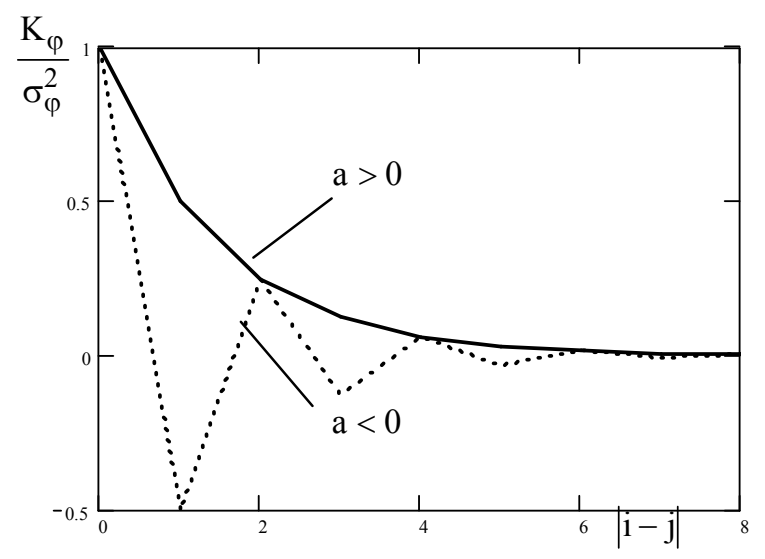

Fig. 1. The laws of change in the correlation of phase fluctuations

The realization of statistical averaging (17) allows us to obtain the expression for the dispersion of the total measurement error of the frequency of a burst of radio pulses with an exponential decrease in phase correlation

$$
\begin{gathered}
\sigma_{\Sigma}^{2}=\frac{12}{q^{2} T^{2}\left(4 m^{2}-1\right)}+\frac{18 \sigma_{\varphi}^{2}}{m^{2} T^{2}\left(4 m^{2}-1\right)^{2}} \times \\
\times\left[\sum_{k=1}^{m}(2 k-1)^{2}\left(1-a^{(2 k-1)}\right)+\right. \\
\left.+2 \sum_{k=1}^{m-1} \sum_{i=1}^{m-k} a^{i}(2 k-1)(2 k+2 i-1)\left(1-a^{(2 k-1)}\right)\right] .
\end{gathered}
$$

According to (17), the expression of the dispersion of the total measurement error of the frequency of a burst of radio pulses with an alternating law of decreasing phase correlation is

$$
\sigma_{\Sigma}^{2}=\frac{12}{q^{2} T^{2}\left(4 m^{2}-1\right)}+\frac{18 \sigma_{\varphi}^{2}}{m^{2} T^{2}\left(4 m^{2}-1\right)^{2}} \times
$$




$$
\begin{gathered}
\times\left[\sum_{k=1}^{m}(2 k-1)^{2}\left(1-(-a)^{(2 k-1)}\right)+2 \times\right. \\
\left.\times \sum_{k=1}^{m-1} \sum_{i=1}^{m-k}(-a)^{i}(2 k-1)(2 k+2 i-1)\left(1-(-a)^{(2 k-1)}\right)\right] .
\end{gathered}
$$

Fig. 2 shows the graphs of the square multiplication of the total error of measuring of the frequency of a burst of ten radio pulses and their repetition period $\left(\sigma_{\Sigma} T\right)^{2}$ from the signal-to-noise ratio of power $q^{2}$ at an exponential (Fig. 2, a) and alternating (Fig. 2, b) laws of decreasing their correlation.
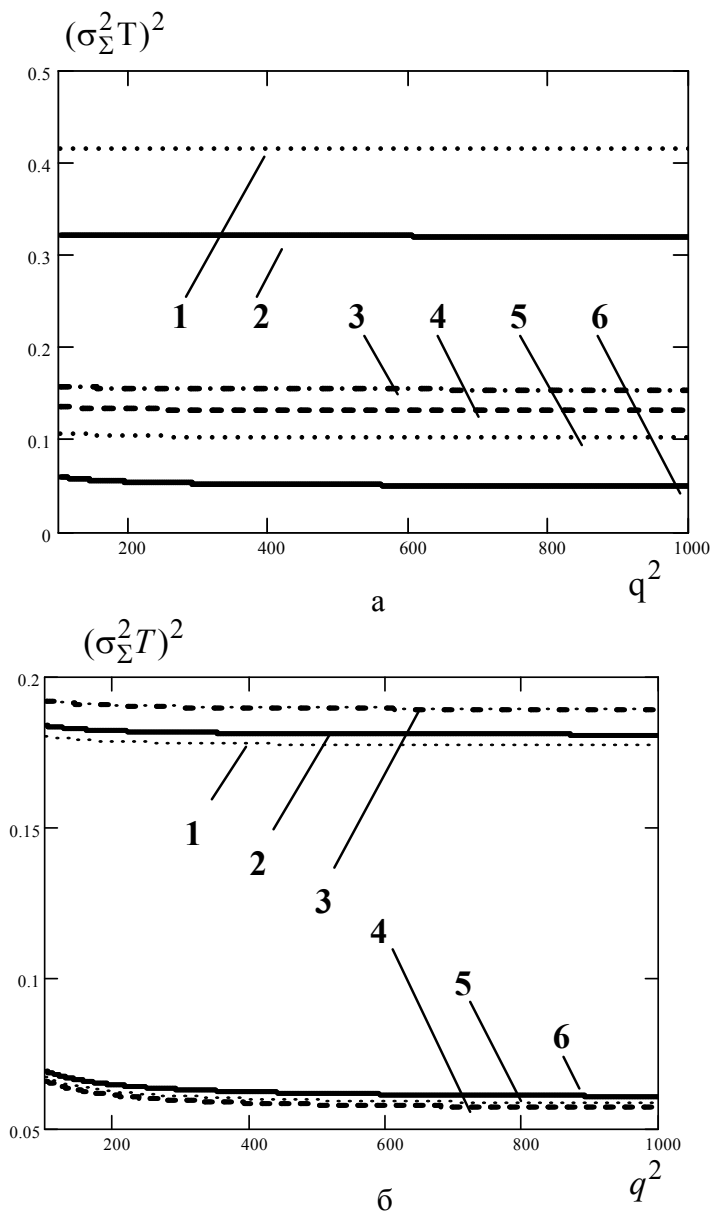

Fig. 2. Dispersion of measurement error of the frequency of the radio pulse burst
Graphs are obtained for the following conditions:

$$
\begin{aligned}
& 1-\mathrm{a}=0,9, \sigma_{\varphi}^{2}=10 \operatorname{Rad}^{2} \\
& 2-\mathrm{a}=0,95, \sigma_{\varphi}^{2}=10 \operatorname{Rad}^{2} \\
& 3-\mathrm{a}=0,99, \sigma_{\varphi}^{2}=10 \operatorname{Rad}^{2} \\
& 4-\mathrm{a}=0,9, \sigma_{\varphi}^{2}=1 \operatorname{Rad}^{2} \\
& 5-\mathrm{a}=0,95, \sigma_{\varphi}^{2}=1 \operatorname{Rad}^{2} \\
& 6-\mathrm{a}=0,99, \sigma_{\varphi}^{2}=1 \operatorname{Rad}^{2}
\end{aligned}
$$

The results are shown in Fig. 2 show that under condition of a regular measurement $\left(q^{2}>>1\right)$, the accuracy of measuring the frequency of a burst of radio pulses is much more affected by the statistical characteristics of phase fluctuations than the signal-tonoise ratio.

With a significant effect of phase fluctuations $\left(\sigma_{\varphi}^{2}=1 \ldots 10 \mathrm{Rad}^{2}, a=0,99 \ldots 0,9\right)$, dispersion of the measurement error of the burst frequency can increase by a value from units to several dozen times as compared with a case of the absence of the influence of phase fluctuations.

With the exponential law of decreasing phase correlation, the influence of the values of the dispersion and coefficient of interpulse correlation of phase fluctuations is equally significant. In the case of the alternating law of decreasing phase correlation, the accuracy of the measurement of the frequency of the burst is much more affected by the dispersion than the interpulse correlation coefficient of the phase fluctuations. Thus, it is necessary to take into account the random phase distortions of the radar signal arising due to the influence of the real conditions of the radar functioning in the algorithms of its time-frequency processing.

\section{Conclusions}

The influence of the real conditions of the radar observation of the leads to the appearance of fluctuations of the initial phases of the radio pulses of the received burst. The accuracy of measuring of the target's radial velocity significantly depends on the statistical characteristics of phase fluctuations, the values of which determine the conditions for optimizing the time-frequency processing of the radar signal.

\section{REFERENCES}

1. Shirman D. (1999), Radioelectronic systems. Basics of construction and theory, Z.A.O. MACVIS, Moscow, 828 p.

2. Karlov, V.D., Leonov, I.G., Prisyazhnyy, A.E. and Lukovsky O.Ya. (2006), "Detection of aerodynamic targets in the conditions of noise and passive interference with a wide Doppler spectrum", Information Processing Systems, KhUPS, Kharkiv, No. 9 (58), pp. 34-36.

3. Karlov, V.D., Minervin, N.N., Petrushenko, N.N. and Lukashuk E.V. (2008), "The effect of the irregularities in the relief of the position of the radar station on the effectiveness of the suppression of external interference at the location of surface targets", Control navigation and communication systems, No. 4 (8), pp. 34-36.

4. Petrushenko, M.M. (2009), "Peculiarities of application of radio systems of the Air Forces in unstable meteorological conditions and natural meteorological phenomena", Control navigation and communication systems, No. 2(10), pp. 54-57.

5. Karlov, V.D., Minervin, N.N., Petrushenko, N.N., Lukashuk, E.V. and Lukovsky O.Ya. (2008), "Influence of fluctuations of the front of an interfering wave on the efficiency of its suppression by a correlation compensator in radio engineering systems of coastal basing", Information Processing Systems, KhUPS, Kharkiv, No. 7 (74), pp. 87-93.

6. Minervin, M.M. and Kuznetsov, O.L. (2001), "Errors of measurement of the radial velocity and radial acceleration of the target, due to the neglect of fluctuations of the phases of the pulses of a pack", Aviation Technologies and Technologies, No. 3 (9), pp. 116-118. 
7. Minervin, M.M., Kuznetsov, O.L. and Tarshin V.A. (2006), "Limiting the accuracy of measuring the radial velocity of the target due to the conditions of propagation, reflection and processing of the radar signal", Collection of scientific works of Kharkiv University of Air Forces, KhUPS, Kharkiv, No. 3 (9), pp. 116-118.

8. Karlov, V.D., Kuznetsov, O.L. and Artemenko A.M. (2018), "Statement of the problem of optimal estimation of the radial velocity of the target, taking into account the correlated fluctuations of the initial phases of the radio pulses of the adopted bundle", Collection of scientific works of Kharkiv University of Air Forces, KhUPS, Kharkiv, No. 3 (57), pp. 115-121.

9. Dhivakar, B., Saravanan, S.V., Sivaram, M. and Krishnan R.A. (2012), "Statistical Score Calculation of Information Retrieval Systems using Data Fusion Technique”, Computer Science and Engineering, Vol. 2, Issue 5, pp.43-45, DOI: http://doi.org/10.5923/j.computer.20120205.01

10. Sivaram, M., Yuvaraj, D., Amin Salih, Mohammed, Porkodi, V. and Manikandan V. (2018), "The Real Problem Through a Selection Making an Algorithm that Minimizes the Computational Complexity", International Journal of Engineering and Advanced Technology, Vol. 8, Iss. 2, 2018, pp. 95-100.

11. Ruban, I., Kuchuk, H. and Kovalenko A. (2017), "Redistribution of base stations load in mobile communication networks", Innovative technologies and scientific solutions for industries, No. 1 (1), pp. 75-81, DOI : http://doi.org/10.30837/2522-9818.2017.1.075

12. Karlov, V.D., Rodjukov, A.O. and Pichugin I.M. (2015), "Statistical characteristics of radar signals reflected from local objects in conditions of abnormal refraction", Science and technology of the Air Forces of the Armed Forces of Ukraine, KhUPS, Kharkiv, No. 4 (21), pp. 71-74.

Received (Надійшла) 10.12.2018

Accepted for publication (Прийнята до друку) 13.02.2019

\section{Оцінювання точності вимірювання радіальної швидкості цілі при експоненційному і знакозмінному убуванні кореляції фази пачкового радіосигналу \\ В. Д. Карлов, О. Л. Кузнєцов, А. М. Артеменко, А. Д. Карлов}

Удосконалення та розвиток сучасних аеродинамічних об'єктів радіолокаційного спостереження викликає збільшення вимог до їх засобів виявлення та відстеження. Збільшення маневруючих можливостей мішеней і здатність їх виконувати поставлені завдання на малих висотах з округленням місцевості обумовлює необхідність оцінки отриманої відстані до мети з різними радарами з максимально високою точністю. Визначення радіальної швидкості мішені при первинній обробці радіолокаційної інформації здійснюється в когерентно-імпульсному радіолокаторі, який використовує когерентний викид радіоімпульсів в якості звукового сигналу. Ступінь когерентності цього вибуху визначає тривалість його фазової структури $\mathrm{i}$, як наслідок, міру дозволу радіальної швидкості і точність вимірювання радіальної швидкості повітряного об'єкта. Метою статті є аналіз впливу статистичних характеристик флуктуацій початкових фаз радіальних імпульсів отриманого когерентного вибуху на зниження точності вимірювання радіальної швидкості мішені. Результати. У статті розглядаються питання оцінювання радіальної швидкості при використанні когерентної пачки радіоімпульсів стосовно випадку наявності у відбитих від цілі радіоімпульсах корельованих флуктуацій початкових фаз. Оцінюється точність вимірювання частоти пачки для випадку узгодженої обробки без врахування фазових флуктуацій іiі радіоімпульсів. Розгляд проводиться у припущенні, що на вхід приймального пристрою РЛС надходить адитивна суміш відбитих від цілей сигналів й некорельованого гаусівського шуму. Вважається, що фазові флуктуації радіоімпульсів прийнятої пачки розподілені за нормальним законом 3 нульовим середнім, а кореляція фазових флуктуацій зі збільшенням інтервалу між радіоімпульсами пачки убуває за експоненціальним або знакозмінним законами. Наведений аналіз дозволяє визначити умови, при яких ускладнення алгоритму обробки даного радіолокаційного сигналу вважається виправданим. Висновки. В результаті досліджень визначено, що вплив реальних умов радіолокаційного спостереження призводить до появи флуктуацій початкових фаз радіоімпульсів повторного спалаху. Точність вимірювання радіальної швидкості мішені значно залежить від статистичних характеристик фазових коливань, значення яких визначають умови оптимізації частотно-часової обробки радіолокаційного сигналу.

Ключові слова: когерентно-імпульсна РЛС; пачка радіоімпульсів; фазові флуктуації; радіальна швидкість; гаусівський шум; радіолокаційне спостереження; ефективність оптимізації.

\section{Оценивание точности измерения радиальной скорости цели \\ при экспоненциальном и знакопеременном убывании корреляции фазы пачечного радиосигнала}

В. Д. Карлов, А. Л. Кузнецов, А. Н. Артеменко, А. Д. Карлов

Целью статьи является анализ влияния статистических характеристик флуктуаций начальных фаз радиальных импульсов полученного когерентного взрыва на снижение точности измерения радиальной скорости мишени. Результаты. В статье рассматриваются вопросы оценивания радиальной скорости при использовании когерентной пачки радиоимпульсов применительно к случаю наличия в отраженных от цели радиоимпульсах коррелированных флуктуацій начальных фаз. Оценивается точность измерения частоты пачки для случая согласованной обработки без учета фазовых флуктуаций. Рассмотрение проводится в предположении, что на вход приемного устройства РЛС поступает аддитивная смесь отраженных от целей сигналов и некоррелированного гауссовского шума. Предполагается, что фазовые флуктуации радиоимпульсов принятой пачки распределены по нормальному закону с нулевым средним, а корреляция фазовых флуктуаций с увеличением интервала между радиоимпульсами пачки убывает по экспоненциальному или знакопеременному законам. Приведенный анализ позволяет определить условия, при которых усложнение алгоритма обработки данного радиолокационного сигнала считается оправданным. Выводы. В результате исследований установлено, что влияние реальных условий радиолокационного наблюдения приводит к появлению флуктуаций начальных фаз радиоимпульсов повторного возгорания.

Ключевые слова: когерентно-импульсная РЛС; пачка радиоимпульсов; фазовые флуктуации; радиальная скорость; гауссовский шум; радиолокационное наблюдение; эффективность оптимизации. 